\title{
Promoting Autonomous Learning and 21st Century Skills of English Education Students Through Empowering Their Pedagogical Skills
}

\author{
Ni Nyoman Padmadewi*, Luh Putu Artini, Dewa Ayu Eka Agustini \\ English Education Department \\ Ganesha University of Education \\ Bali, Indonesia \\ *nym.padmadewi@undiksha.ac.id, putu.artini@undiksha.ac.id
}

\begin{abstract}
Autonomous learning skill is one of the skills demanded to survive in the $21^{\text {st }}$ century. Students need to selfdirect themselves and show how their skills can match $21^{\text {st }}$ Century learning needs. However, the results of observations in several departments of education universities in North Bali reveals that teachers face challenges and problems on how students' $21^{\text {st }}$ century learning skills can be empowered. This research is aimed at empowering the pedagogical skills, autonomous learning, and $21^{\text {st }}$ century learning skills of the teacher candidates through a continuous clinical supervision model of teaching practices during Microteaching Class at an education university in North Bali. The study was in the form of embedded mixed method design, and implemented towards Microteaching classes of English Education Students in 2018. The data was collected using observations, questionnaires and also through tests, and analyzed qualitatively as well as quantitatively. The results of the study showed that there are obvious differences between the teacher candidates' performances before and after the implementation. Their pedagogical skills and self-directed learning improved satisfactorily. The continuous clinical supervision models applied and actions provided during the teaching practices improved the pedagogical skills, self-directness and $21^{\text {st }}$ century learning skills of the teacher candidates. With the improved skills, it is expected that they will become more skilled future teachers of the $21^{\text {st }}$ century generation.
\end{abstract}

Keywords: autonomous learning, pedagogical skills, 21st century skills

\section{INTRODUCTION}

In terms of concept, learner autonomy has been widely introduced since 1980s; however its implementation in Indonesia has just been recently empowered as demanded by the era of the 21 st century. This 21 st century is indicated by fast technology and instant action which requires every citizen to be able to take initiative and self-direct themselves.

Learner autonomy has been attracting a lot of attention from many researchers. In different studies learner autonomy has been defined differently. It is stated as 'the ability to take charge of one's own learning, and to take charge of one's own learning is to have, and to hold the responsibility for all the decisions concerning all aspects of this learning [1]. It is not inborn but must be acquired by 'natural' means or (as most often happens) by formal learning, i.e. in a systematic deliberate way [2]. Learner autonomy is applicable to multiple usage such as: situations in which the students can study on their own, a set of skills which can be learned and applied in self-directed learning, an inborn capacity which is suppressed by institutional education, the exercise of learners' responsibility for their own learning., and the right of the learners to determine the direction of their own learning [3]. Autonomous learners have a clear understanding about the purpose of their learning, high responsibility for their own learning, able to take initiatives in planning and conducting their learning tasks and activities and capable of making their own reflections [4]. Autonomous learners must have wide knowledge, high commitment and positive attitudes, capacity of reviewing and making reflections and being able to selfmanage themselves. Previous literature has shown the importance of learner autonomy which is basically a part of an individual process which leads them to be the agents of their own learning, shifting the roles of the teachers from being the source of information to be the students' helper in seeking their own way of exploring more knowledge and information.

In this era of 21 st century learning, the skill of autonomous learning is a necessity because not everything can be taught in the classroom; meanwhile there are abundant resources available online. The students as well as the teachers need to be prepared in how they are able to have the skill of autonomous learning in order to self-direct themselves in order to be able to survive in this era.

Partnership for 21st Century Learning has developed a framework of 21st century education [5]. Teachers are the main factor that contributes to students' performance in mastering 21 st century skills which consist of 4C's: i) creativity, ii) communication, iii) collaboration and v) critical thinking skills [6]. In relation to this, there are several characteristics of $21 \mathrm{st}$ century teachers such as being an adaptor, being a visionary, being a collaborator, a risk taker, a communicator, being a learner, a model, and being a leader [7]. To be able to have 
University of Education (UNDIKSHA) in 2018. The class consisted of 25 students. For the sake of Microteaching Class, during the simulations, the class was divided into two smaller classes and taught by the same lecturer in two different sessions every week. Every class was treated equally using a guiding list of what-to-do as a scaffold. The actions were in the form of clinical steps conducted in cycles each of which consisted of planning, simulation and observation, feedback and reflections. During the planning the students were provided with a guiding list of what-to-do and explanation about the list. This planning session was conducted a week before the presentation time, so the students could prepare themselves well. During the presentation, the student teachers were also guided with another list of what-to-do which had been judged by experts [14] as a scaffolding activity which directed the students on how and what to do to guide themselves. During the simulation, the lecturer and other students were observing. After the simulations, all student teachers and the lecturer had discussion and gave input which was used as feedback for the next planning. These cycles were conducted every week until the semester ended. The data was collected through observations, formative assessments, and also interviews. The data was analyzed qualitatively as well as quantitatively using descriptive and inferential statistics.

\section{RESULTS AND DISCUSSION}

The learning autonomy of the student teachers improved after one semester of treatment. The student teachers were scaffold for about one semester on how to make a correct and good lesson plan. The scaffold was in the form of a guiding list of what-to-do (as shown in Table 2) which contains 10 statements to direct the student teachers in making the lesson plans. Before the treatment was conducted the student teachers had been showing basic competencies of making a lesson plan because the students had taken several related pedagogical subjects (like curriculum and instructional design; Teaching English as a Foreign Language; Assessment). Despite the contributions of these subjects, the fact was that at the first sessions of the Microteaching Class, the student teachers still showed their limitations in the lesson plans they made: the indicators still used un-operational words and some were not clear; the character values and $21^{\text {st }}$ century skills were not well inserted in the activities; and the assessments were not authentic and still emphasized recognition instead of production-type of assessments. This is in line with the result of the previous study pertaining to revitalization of Teaching English as a Foreign Language for $21^{\text {st }}$ century learning [15] that the $21^{\text {st }}$ century skills of the student need to be improved.

During one semester of treatment, the students were guided on how they should improve their lesson plans. The students were slowly yet convincingly able to improve the quality of the lesson plans; and their self-directed learning skill was also improving. Table 1 shows its improvement in detail indicated by the scores ranged from 1(lowest) to 4 (highest). action research. The study was conducted in Microteaching Class of English Language Education Department at Ganesha 
TABLE II. THE IMPROVEMENT OF STUDENTS' COMPETENCE IN LESSON PLANNING AFTER THE TREATMENT PROVIDED

LEARNERS DURING LESSON PLANNING

\begin{tabular}{|c|c|c|}
\hline \multirow[t]{2}{*}{ Self-Directed Learning Skills } & \multicolumn{2}{|c|}{$\begin{array}{l}\text { Student teachers' self- } \\
\text { rating score }\end{array}$} \\
\hline & 4 & 3 \\
\hline \multicolumn{3}{|l|}{$\begin{array}{l}\text { 1. The student teachers are able to direct themselves } \\
\text { in developing lesson plans. }\end{array}$} \\
\hline $\begin{array}{l}\text { a. the students freely choose and design lesson } \\
\text { plans }\end{array}$ & $96.00 \%$ & $4 \%$ \\
\hline $\begin{array}{l}\text { b. the lesson plan has been based on the syllabus. } \\
\text { c. the approach, methods and techniques used has }\end{array}$ & $100 \%$ & \\
\hline $\begin{array}{l}\text { been innovative and following the philosophy of } \\
\text { the newest curriculum applied. }\end{array}$ & $96 \%$ & $4 \%$ \\
\hline $\begin{array}{l}\text { d. the assessments have been planned based on } \\
\text { the indicators of the competencies. }\end{array}$ & $80.00 \%$ & $20.00 \%$ \\
\hline \multicolumn{3}{|l|}{$\begin{array}{l}\text { 2. The student teachers have been the agents of } \\
\text { their own learning in designing the process of } \\
\text { teaching and learning which include: }\end{array}$} \\
\hline $\begin{array}{l}\text { a. helping their students' understanding to } \\
\text { establish competency }\end{array}$ & $96.00 \%$ & $4.00 \%$ \\
\hline $\begin{array}{l}\text { b. designing innovative and fun learning in the } \\
\text { classroom }\end{array}$ & $76.00 \%$ & $24.00 \%$ \\
\hline $\begin{array}{l}\text { c. inserting character values and } 21^{\text {st }} \text { century } \\
\text { learning }\end{array}$ & $20.00 \%$ & $80.00 \%$ \\
\hline $\begin{array}{l}\text { d. designing appropriate and relevant assessment } \\
\text { to assess the indicators of the competencies and } \\
\text { the success of teaching learning process. }\end{array}$ & $24.00 \%$ & $76.00 \%$ \\
\hline \multicolumn{3}{|l|}{$\begin{array}{l}\text { 3. The student teachers have been independently } \\
\text { able to design follow-up activities as the closure of } \\
\text { the teaching learning process. }\end{array}$} \\
\hline a. reviewing the materials which include students. & $100.00 \%$ & \\
\hline $\begin{array}{l}\text { b. providing extended activities and summary to } \\
\text { close the lesson. }\end{array}$ & $100.00 \%$ & \\
\hline
\end{tabular}

Table 1 shows that the student teachers' self-directed skills at the end of the semester was obvious. It was indicated by the changes of their behavior and performances in preparing the lesson plans. At the beginning almost all of them consulted their lesson plans, and not able to fulfill the criteria of the list provided. Most of them got $60 \%$ because the indicators in the lesson plans were not developed based on the criteria, and the lesson plans made did not accommodate the character values and $21^{\text {st }}$ century skills. From their performances, it can also be observed that the student teachers frequently wanted to check the lesson plans or asked for advices and ideas.

With the list provided and discussions in the classroom and outside the classrooms before the simulations their skill improved obviously. The competencies of individual student in making lesson plans was also improving as indicated in Table 2.

\begin{tabular}{|c|c|c|c|}
\hline $\begin{array}{c}\text { Student } \\
\text { Teachers }\end{array}$ & Before & $\begin{array}{c}\text { Treatment (guiding list of } \\
\text { what- to- do as scaffold) }\end{array}$ & After \\
\hline 1 & $60.00 \%$ & \multirow{26}{*}{$\begin{array}{l}\text { 1. I already referred to the } \\
\text { syllabus and course contract } \\
\text { before the lesson plan was made. } \\
\text { 2. I already used the guideline of } \\
\text { lesson plan used in the school. } \\
\text { 3. I develop indicators based on } \\
\text { the statements of competency } \\
\text { stated in the syllabus, which } \\
\text { contain the following elements: } \\
\text { A= Audience } \\
\text { B= behavior } \\
\text { C= condition } \\
\text { D=degree } \\
\text { 4.Statements of objectives are } \\
\text { clear } \\
\text { 5. Material is relevant and in } \\
\text { accordance } \\
\text { development of the lessons. } \\
\text { 6. The lesson plan } \\
\text { accommodates character values, } \\
\text { skills for } 21^{\text {st }} \text { century and skills } \\
\text { of high order thinking. } \\
\text { 7.The approach and method used } \\
\text { is clear and relevant } \\
\text { 8.The media /audio visual aids } \\
\text { utilized is meaningful } \\
\text { Steps of teaching: } \\
\text { Clear and help s' understanding. } \\
\text { Innovative } \\
\text { Stimulating high order thinking } \\
\text { skill } \\
\text { Providing enough chances for } \\
\text { the s to use the target language } \\
\text { the s were learning } \\
\text { Using effective classroom } \\
\text { management. } \\
\text { Providing opportunities for s to } \\
\text { experience new things and guide } \\
\text { them to construct new } \\
\text { knowledge based on the } \\
\text { experience } \\
\text { Interesting } \\
\text { 9.Assessment: } \\
\text { Assess what supposed to be } \\
\text { assessed } \\
\text { Relevant } \\
\text { Authentic } \\
\text { Based on the indicators } \\
\text { Clear and not ambiguous } \\
\text { Provided with rubric } \\
\text { 10.Closure: } \\
\text { Lead s to conclude the } \\
\text { instruction } \\
\text { Relevant and meaningful closure }\end{array}$} & $90.00 \%$ \\
\hline 2 & $60.00 \%$ & & $100.00 \%$ \\
\hline 3 & $60.00 \%$ & & $80.00 \%$ \\
\hline 4 & $80.00 \%$ & & $80.00 \%$ \\
\hline 5 & $60.00 \%$ & & $100.00 \%$ \\
\hline 6 & $60.00 \%$ & & $100.00 \%$ \\
\hline 7 & $80.00 \%$ & & $100.00 \%$ \\
\hline 8 & $50.00 \%$ & & $80.00 \%$ \\
\hline 9 & $60.00 \%$ & & $100.00 \%$ \\
\hline 10 & $60.00 \%$ & & $100.00 \%$ \\
\hline 11 & $80.00 \%$ & & $100.00 \%$ \\
\hline 12 & $80.00 \%$ & & $100.00 \%$ \\
\hline 13 & $60.00 \%$ & & $80.00 \%$ \\
\hline 14 & $60.00 \%$ & & $100.00 \%$ \\
\hline 15 & $80.00 \%$ & & $80.00 \%$ \\
\hline 16 & $80.00 \%$ & & $100.00 \%$ \\
\hline 17 & $50.00 \%$ & & $80.00 \%$ \\
\hline 18 & $80.00 \%$ & & $100.00 \%$ \\
\hline 19 & $80.00 \%$ & & $100.00 \%$ \\
\hline 20 & $60.00 \%$ & & $80.00 \%$ \\
\hline 21 & $60.00 \%$ & & $100.00 \%$ \\
\hline 22 & $80.00 \%$ & & $100.00 \%$ \\
\hline 23 & $80.00 \%$ & & $80.00 \%$ \\
\hline 24 & $80.00 \%$ & & $80.00 \%$ \\
\hline 25 & $80.00 \%$ & & $100.00 \%$ \\
\hline & & & \\
\hline
\end{tabular}

From Table 2, it is obvious that the scaffold provided had improved students' ability in making lesson plans. Similar improvement was also clearly seen during the implementation of the teaching skills. With intensive guidance through scaffolding activities and the list provided as well as the feedback from peers and lecturers during one semester $/ 26$ weeks, the improvement of the student teachers on their pedagogical skills was significant. The detail of the improvement is summarized in Table 3. 
Besides the self-directed learning skills and the pedagogical skills of the student teachers, the $21^{\text {st }}$ century skills of the student teachers have also improved. Table 4 shows the details of the improvement.

TABLE IV. THE IMPROVEMENT OF THE STUDENTS' $21^{\text {st }}$ CENTURY SKILLS

\begin{tabular}{|c|c|c|c|c|c|c|c|c|}
\hline \multirow[t]{2}{*}{$\mathbf{2 1}^{\text {st }}$ Century Skill } & \multicolumn{4}{|c|}{$\begin{array}{c}1^{\text {st }} \text { week of } \\
\text { Microteaching Class }\end{array}$} & \multicolumn{4}{|c|}{$\begin{array}{c}26^{\text {th }} \text { week of Microteaching } \\
\text { Class } \\
\end{array}$} \\
\hline & 1 & 2 & 3 & 4 & \begin{tabular}{l|l} 
& 1 \\
\end{tabular} & 2 & 3 & 4 \\
\hline $\begin{array}{l}\text { 1.Life and Career } \\
\text { skill }\end{array}$ & & & & & & & & \\
\hline $\begin{array}{l}1.1 \text { Flexibility and } \\
\text { adaptability }\end{array}$ & & $80 \%$ & $20 \%$ & & & & $60 \%$ & $40 \%$ \\
\hline $\begin{array}{l}1.2 \text { Initiative and } \\
\text { self- direction }\end{array}$ & & $100 \%$ & & & & & $80 \%$ & $20 \%$ \\
\hline 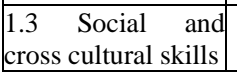 & & $20 \%$ & $80 \%$ & & & & & $100 \%$ \\
\hline \begin{tabular}{|lr}
1.4 & Productivity \\
and accountability
\end{tabular} & & $80 \%$ & $20 \%$ & & & & $96 \%$ & $4 \%$ \\
\hline $\begin{array}{l}1.5 \text { Leadership and } \\
\text { responsibility }\end{array}$ & & $60 \%$ & $40 \%$ & & & & $96 \%$ & $4 \%$ \\
\hline $\begin{array}{l}\text { 2. Innovation and } \\
\text { learning skill }\end{array}$ & & & & & & & & \\
\hline $\begin{array}{l}2.1 \text { Creativity and } \\
\text { innovation }\end{array}$ & & $60 \%$ & $32 \%$ & $8 \%$ & & & $80 \%$ & $20 \%$ \\
\hline $\begin{array}{|lr|}2.2 & \text { Critical } \\
\text { thinking } & \text { and } \\
\text { problem solving }\end{array}$ & & $80 \%$ & $20 \%$ & & & $76 \%$ & $20 \%$ & $4 \%$ \\
\hline \begin{tabular}{|l|}
2.3 \\
Communication \\
and collaboration
\end{tabular} & & $20 \%$ & $76 \%$ & $4 \%$ & & & & $100 \%$ \\
\hline $\begin{array}{|lr|}\text { 3. } & \text { Information, } \\
\text { Media } & \text { And } \\
\text { Technology } & \text { Skills } \\
\end{array}$ & & & & & & & & \\
\hline \begin{tabular}{|l|l|}
3.1 Media \\
\end{tabular} & & $20 \%$ & $80 \%$ & & & & $96 \%$ & $4 \%$ \\
\hline 3.2 Technology & & & $80 \%$ & $20 \%$ & & & & $100 \%$ \\
\hline
\end{tabular}

Table 4 shows the improvements of the students' 21 st century skills. At the beginning of the semester, some students were still left behind in spite of their generic pedagogical skills which were clearly presented. Their social and cross cultural skills were quite strong, and also their technological competence. They were socially cooperative and understood each other. They also indicated good skill of using technology, however still about 5 persons or (20\% of the students) need improvement especially on how animations of the power point can be utilized appropriately. With continuous guidance provided during reflections and discussions, students learned from peers as well as from the lecturers. Finally, they improved their skills.

Flexibility and adaptability have improved. This was indicated by the ability of the student teacher to modify songs and games provided online into the ones needed for their class. Problem solving activities was also improved which was indicated by the project and problem-based learning activities designed by the student teachers. The critical thinking was improved by training their students with asking questions through games.

The $4 \mathrm{C}$ (communication, collaborations, critical thinking and creativity) of the student's teachers also improved. The use of English all the time during the practice and simulations improved the quality of explanations so the communication interactions in the classroom ran effectively; collaborations 
before and during the presentations sessions also indicated improvements. Creativity and critical thinking improvements were also obvious which was indicated by the project and problem-based learning designed by the student teachers.

Analyzing the findings revealed in this study, it is obvious that guidance either in the form of guiding lists of what-to-do, or verbal discussions and feedback during reflections were significantly important which functioned as beneficial scaffolds for students, especially during the first weeks of the activities. The scaffolds help students what to do and how they should do the activities. Scaffolding can function as a technique which provides students with instructional guidance, collaborations and temporary support by the teacher to accomplish the tasks and targeted objectives [16]. The scaffolds in the forms of lists of what-to-do direct students what they should do and how they should do the activities. The lists were used all the time until they were not needed anymore and students could self-direct themselves.

Referring to the gradual improvements manifested in the students' performances, what was described in the previous study that learner autonomy is not inborn but acquired in a systematic and deliberate way is reconfirmed in this study [2]. The systematic actions conducted in clinical actions assisted students to identify their mistakes and find out the solutions. The lists direct students on what to do and how the teaching learning process must be conducted. The reflections conducted helped students to look inside and self-assess themselves. The discussions with peer and the lecturer guides students to find solutions for their improvements. These systematic procedures were conducted 26 times and the clinical advice was able to make contributions to the student teachers' improvement.

The list of what-to-do during lesson planning also obviously improved the student teachers' learning autonomy skills. At the beginning of the semester, most of them lacked initiative and mostly needed advice and guidance. From the lists of what-to-do, the student teachers knew what to do, and they only came for consultations if they found difficulties. The character values for example, initially were only labeled in the lesson plans and classroom activities did not reflect the values they wanted to insert. However, with clinical supervisions and discussions student teachers were directed by the teachers on how to find learning resources and how to modify them and apply them in the classroom. The list of what-to-do during presentations and simulations were also very effective. The list as stated in Table 4 clearly assisted students in practicing every basic skills of Microteaching. In every simulation, the list was used by the student teachers and they were guided step-by-step. The practices and reflections in the classrooms were reconfirming the student teachers on what to improve and how to improve it.

The characteristics of $21 \mathrm{st}$ century teachers were also indicated in the student teachers' behavior. Following the characteristics of the 21 st century teachers [7], it is evident that the student teachers have been improving and be able to show their behaviors reflecting those characteristics. They were adaptive because they have been able to adapt and modify certain learning material into students' levels and needs. They have also been very collaborative in doing their group works or sharing new ideas and supporting each other; and also been able to communicate ideas and share problems in discussions. The social and cross cultural skills were also presented well; they have been able to show tolerant behavior and mutually understand each other. They have been also showing a character of being a leader when they were managing their tasks. The one characteristic which was not clearly manifested was being a risk taker. The situation of learning and exploring new learning material for one semester showed that being a risk taker is not obvious. Despite that limitation, the student teachers' responsibility in handling all the decisions concerning their own learning has been developed. They have been able to take charge of their own learning either in designing lesson plans, teaching learning process or in assessments. Their learner autonomy has been promoted.

The holistic guidance provided has functioned as scaffolding strategies which temporarily supported students and finally on the last 6 weeks of the semester, they all selfdirected themselves. During the whole semester, student teachers showed their commitment and hardworking characters which also supported the improvement, and reflected the character of autonomous learners. These positive commitment and attitude they had along the semester was vital for the development of learning autonomy. This is in line with the opinion stated by previous researcher [4] that the practice of learning autonomy needs insight, positive attitude and a capacity for reflections, and readiness to be proactive in selfmanagement and making interactions with others.

The importance of promoting students' responsibility for their own learning also reconfirmed other researchers [17]. They describe that there are three reasons for that: 1) learning can be more effective when the students take control of their own learning because they learn what they want to learn; 2) the students who are responsible for their own learning can carry out their learning outside the classroom; 3) the students who know about learning can transfer their learning strategies to other subjects.

The effectiveness of the actions in promoting learner autonomy and $21^{\text {st }}$ century learning is applicable to all teachers in the global context especially for teachers who teach English as a foreign language. Moreover, $21^{\text {st }}$ century requires English skill which is basic to survive in this era of technology. Being effective teachers in the $21^{\text {st }}$ century is the demand to prepare students for the betterment and successful achievement in learning, life and work [12].

Despite that the present study showed effective results, the study was only conducted in Microteaching Class where the students they taught were their peers, not real students who demand different challenges and difficulties. It is therefore evident that further research is recommended by conducting similar research but using the subjects of real students and in the real setting of the classroom.

\section{CONCLUSION}

The effectiveness of the cyclic actions in the form of clinical supervision in Microteaching Class, which functions as scaffolds for improving the pedagogical skills and in promoting learner autonomy and $21^{\text {st }}$ century skills, needs intensive 
[5] J. Bishop, Partnership for 21stCentury Skills (P21), 2016 [Online] Retrieved from: https://www.imls.gov/assets/1/AssetManager/Bishop Pre-Con 2.pdf.

guidance and high commitment from lecturers. Lecturers are needed to provide their commitment to identify the student teachers' needs and problems and help them find the solutions. For the student teachers, the development of learner autonomy and $21^{\text {st }}$ century skills require process and positive attitudes to develop their competence and continuous reflections for improvement. Both the lecturers and the student teachers should be able to cooperatively understand each role and slowly change it from the teachers as the director of the instructions to the helper and the students shift their roles into the agents of their own learning.

\section{ACKNOWLEDGMENT}

The authors of this study would like to extend their appreciation to the lecturers and students for their serious involvement in this research. Special appreciation and high gratitude are forwarded to the Rector of Ganesha University of Education Bali who has supported this study (Undiksha) through the Centre of Research and Community Service of Undiksha.

\section{REFERENCES}

[1] H. Holec, Autonomy in Foreign Language Learning. Oxford: Pargamon, 1981.

[2] P. Benson and P. Voller, Autonomy and independence in language learning. Routledge, 2014

[3] A. Ounis, "Investigating the impact of autonomous learning on developing the learners' oral skills," International Journal of Humanities and Cultural Studies (IJHCS) ISSN 2356-5926, vol. 2, no. 4, pp. 884903, 2016.

[4] D.G. Little, Learner autonomy: Definitions, issues and problems. Authentik Language Learning Resources, 1991.
[6] N.M. Rusdin, "Teachers Readiness in implementing 21st Century Learning," International Journal of Academic Research in Business and Social Sciences, vol. 8, no. 4, pp. 1293-1306, 2018.

[7] A. Churches, Teaching Skills: What 21st Century Educators Need To Learn To Survive, 2009.

[8] I. Sural, "21st century skills level of teacher candidates," European Journal of Education Studies, 2017.

[9] Hendar, The Implementation of Nunan's Autonomous Language Learning Model (NALLM) to EFL Students of Widyatama University In: Teaching and Learning in The 21th Century (Challenges for Lecturers and Teachers). 2014. p. 114-22.

[10] H. Jan, "Teacher of 21 st Century: Characteristics and Development," Res Humanit Soc Sci. vol. 7, no. 9, pp. 50-4, 2017.

[11] J. Faulkner and G. Latham, "Adventurous Lives: Teacher Qualities for 21st Century Learning," Aust J Teach Educ., vol. 41, no. 4, pp. 137-50, 2016.

[12] N. Handayani, "Becoming the Effective English Teachers in the 21st Century: What Should Know and What Should Do?," In English Language and Literature International Conference (ELLiC) Proceedings, vol. 1, pp. 156-164, 2017.

[13] Z. Mahamod and M.D.Z. Mahamod, Memperkasa Guru, Mempercekap Pelajar: Pengajaran dan Pembelajaran Bahasa Melayu Dalam Abad Ke21. In Kertas Kerja Ucaptama di Seminar Bahasa Melayu Singapura, 2011.

[14] N.N. Padmadewi, L.P. Artini, D.A.E. Agustini, Pengantar Micro Teaching. Depok: Raja Grafindo Persada, 2017.

[15] N.N. Padmadewi, L.P. Artini and P.K. Nitiasih, "Revitalizing Teaching English as a Foreign Language Course for 21st Century Learningm," In 1 st International Conference on Education Social Sciences and Humanities (ICESSHum 2019), 2019.

[16] Y. Susanti, "Does Scaffolding Help Students to Write Better?," English Teach J. vol. 2, no. 2, pp. 9-15, 2014.

[17] G. Ellis and B. Sinclair, Learning to learn English. UK: Cambridge University Press, 1989. 